\title{
Characterization of Bacterial Isolates Cultured from the Nasopharynx of Children with Sickle Cell Disease (SCD)

\section{Abstract}

Background: We characterized bacterial isolates from the nasopharynx of 84 Sickle cell disease patients 78 of whom were HbSS and $6 \mathrm{HbSC}$ aged 4 four months to 15 years at Wesley Guild Hospital, Ilesa, southwestern Nigeria between February-September, 2014.

Method: Sterile cotton-tipped initially dipped into sterile saline thereafter was introduced into nasopharynx of each patient and thereafter applied onto sterile thioglycolate medium and incubated at $370 \mathrm{C}$ for $24 \mathrm{hr}$, When growth was noticed, samples were inoculated onto enriched, selective and differential bacteriologic media. Bacterial colonies that grew on such media were picked and characterized by Grams' reaction, cultural, morphologic and biochemical methods. Antibiotic sensitivity tests were determined by the disc diffusion method. Demographic data relating to severity of SCD were provided.

Results: Altogether, 119 isolates were cultured from the nasopharynx. Gram positive bacteria predominated (65.54\%) and Corynebacterium spp (44.53\%) dominated comprising of 19 (35.84\%) Corynebacterium xerosis 11 (20.75\%) Corynebacterium diphtheriae, 10 (18.86) Corynebacterium pseudodiphtheriticum, 8 (15.09\%) Corynebacterium ulcerans, 3 (6.66\%) Corynebacterium spp and 2 (3.77\%) Corynebacterium jeikeium. Other Gram positive rods cultured were Arcanobacterium haemolyticum 6 (5\%). Bacillus subtilis was $3(2.5 \%)$, Actinomyces isrealli 3 (2.5\%) and Norcadia asteroids 1 (0.84\%). Low frequency of nasopharyngeal colonization recorded for Haemophilus influenzae $4.2 \%$, S. pneumoniae $2.5 \%$ and S. aureus 4 (3.36\%) and multiresistance was widespread for most isolates.
Kwashie Ajibade Ako-Nai ${ }^{1}$, Blessing Itohan Ebhodaghe", Adegoke Samuel Ademola², Kuti Bankole Peter², Olakunle O Kassim ${ }^{3}$

1 Department of Microbiology, Faculty of Science, Obafemi Awolowo University, Ile-Ife, Osun State, Nigeria.

2 Department of Paediatrics and Child Health, College of Health Sciences,

Obafemi Awolowo University, Ile-Ife, Osun State, Nigeria.

3 Department of Microbiology, Howard University College of Medicine, Washington DC, United States.

Contact information:

Kwashie Ajibade Ako-Nai.

” kwashajibad@yahoo.com 
Conclusion: Indigenous microflora Corynebacterium spp predominated and low rate of nasopharyngeal colonization with $H$. influenzae, and S. pneumoniae recorded attributable to prophylactic use of penicillin and vaccines administration probably suppressed growth of organisms and inevitably increased resistance to many antibiotics.

\section{Keywords}

SCD patients, nasopharyngeal bacterial isolates, Antibiotic resistance, MAR index.

\section{Introduction}

A recent report shows about one hundred and fifty thousand infants are born annually with sickle cell disorder in Nigeria [1]. The country also ranks highest in the incidence of sickle cell trait in Africa [1]. According to a recent release by the Sickle Cell Foundation of Nigeria, one out of four Nigerians carries the sickle cell gene compared with the United States of America where one in twelve of African Americans carry the sickle cell gene [1]. It has been shown nasopharyngeal bacterial colonization is common in the young infants which often precedes development of invasive diseases [2]. Knowledge of nasopharyngeal bacteria colonization in children is desirable because the nasopharynx harbors potential pathogens. Studies from the eastern and southern parts of Nigeria reported different types of bacterial agents cultured from the nasopharynx of children with sickle cell disease [3]. The types and number of nasopharyngeal bacteria recovered SCD patients depend on number of factors relating to the subject and administration of vaccines and antibiotics that suppress resident microflora but increase emergence of resistant strains [4]. Some investigators have shown the use of vaccines mitigate the incidence of bacterial agents such as S. pneumoniae, Haemophilus influenzae type $b$ and Neisseria meningitidis which influence the carrier rate of these bacteria often implicated in acute bacterial meningitis [5]. For example in the United States, prior to the introduction of Haemophilus influenzae and pneumococcal vaccines, young children below the age of five years with SCD had a $13 \%$ risk of developing bacterial sepsis with mortality rate of 30 and $10 \%$ in patients with sepsis and meningitis [6]. A recent study of the nasopharyngeal of $S$. pneumoniae carriage among rural Gambian in West Africa sub- region, showed the nasopharynx carriage of Gambia infants by S. pneumoniae is rapid and highly dynamic, rising from prevalence of $1.5 \%$ at birth to $77 \%$ at 2 months, 5 months $86 \%$ and to $78 \%$ at 12 months [7]. A Brazilian study reported the nasopharynx may constitute an ecological reservoir or source of dissemination of $S$. pneumoniae, $H$. influenzae, S. aureus and other Gram- negative bacilli (GNB) [2]. Infants and children are the most vulnerable to opportunistic infections mainly because of their relatively immature immune system besides the elderly and the immunocompromised. We have characterized the bacterial isolates from the nasopharynx of sickle cell disease children attending the infant welfare clinic (IWC) at the Wesley Guild Hospital, Ilesa, southwestern Nigeria because the pattern of colonization, types and number of bacterial isolates from nasopharynx may differ from those reported from other regions. In addition, the study also evaluated the antibiotic resistant profile of the potential pathogenic bacterial isolates since this is an antibiotic pressurized community. We also evaluated the severity or otherwise of SCD in these patients in relation to frequency of blood transfusion and hospitalization. We believe the results obtained from our study will assist clinicians to better manage bacterial infections in children with SCD. 


\section{Methods}

\section{Study Center}

Ilesa where the study took place is a semi-urban town with a population of 277,904 inhabitants in Osun State in southwestern Nigeria and the Wesley Guild Hospital is one of the outpost hospitals employed by the Obafemi Awolowo University Hospitals Complex (OAUTHC) to train medical students and other allied healthcare professionals. The hospital is located about 20 minutes' drive from lle-Ile where Obafemi Awolowo University, the parent institution is situated.

\section{Criteria inclusion}

All participants were sickle cell disease patients that attended the infant welfare clinics of the hospital either because they were sick or had a routine checkup appointment with the attending physician. Each participant was recruited after we adequately explained the purpose of the study using each participant's native dialect. Furthermore, demographic information relating to the each participant was obtained from interviews, questionnaire responses from guardian/ parent and case files managed by the attending physicians. Ethical clearance for approval to undertake the study was given by the Ethics committee of the hospital. The age of the participants ranged from 4 months to 15 years comprising of 45 males and 39 females.

\section{Collection of samples}

Each sample was collected from each subject's pharynx by the attending physician using a sterile cotton- tipped applicator that was initially dipped into sterile normal saline and introduced into sterile thioglycolate broth. All such samples were incubated at $37^{\circ} \mathrm{C}$ for 24 hours for growth and further studied. Duplicate samples were prepared for anaerobes and incubated in AnaeroPack Jar 2.5 Liter, Order No.50-25, product of Mitsubishi Gas
Chemical Company Co., Inc. Japan. All samples were analyzed within 24 hours of collection.

\section{Methods of isolation}

The bacterial isolates were identified by Gram stain and growth characteristics on mannitol salt agar (Oxoid, Basingstoke, UK), blood agar, eosinmethylene blue agar, triple sugar iron agar, sulfide indole motility medium, citrate agar (Oxoid) and Analytical Profile index (API) rapid biochemical test. API kits used include API20E and API Staph (Biomerieux, France). Coagulase and catalase tests and sensitivity to Taxo A (0.04 units of bacitracin) and Taxo P $(5 \mu \mathrm{g})$ ethylhydrocupreine hydrochloride (optochin; BD Diagnostics, Difco Laboratories, Detriot, USA) were also employed for identification. All bacterial isolates were tested for their sensitivity to commonly prescribed antibiotics using the KirbyBauer method. The antibiotics used were obtained from Abtek Biologicals Limited (Liverpool, UK) and included erythromycin $(15 \mu \mathrm{g})$, gentamicin $(10 \mu \mathrm{g})$, agumentin $(30 \mu \mathrm{g})$, streptomycin $(10 \mu \mathrm{g})$, tetracycline $(10 \mu \mathrm{g})$, chloramphenicol $(10 \mu \mathrm{g})$, nalidixic acid $(30 \mu \mathrm{g})$, ampicillin $(10 \mu \mathrm{g})$, nitrofurantoin $(200 \mu \mathrm{g})$, ciprofloxacin $(5 \mu \mathrm{g})$, ceftriaxone $(30 \mu \mathrm{g})$, oxacillin (1 $\mu \mathrm{g})$, kanamycin $(30 \mu \mathrm{g})$, and. S. aureus ATCC 25923 and Enterobacter aerogenes (American Type Culture Collection, Rockville, USA) were used as control organisms.

\section{Statistical analysis}

The resulting data was analysed by the descriptive analysis and t-test using SPSS version 16.0 software. Significant difference was taken as $p<0.05$.

\section{Results}

Data relating to patients' were obtained from their records and personal files and analyzed. Table 1 shows the profile of the genotype, the frequency of blood transfusion and hospitalization of the 
SCD patients. Out of the 84 SCD patients screened, 78 (92.85\%) were HbSS of which 41 (52.5\%) male and $37(47.4 \%)$ female compared to 6 with HbSC of which $4(66.7 \%)$ was male and 2 (33.3\%) female. The number of blood transfusion in the 12 months prior the study was analyzed. Of the 81 patients whose records were available, 1 patient received blood transfusion 4 times; another patient had 3 blood transfusions within the period. 5 patients also received blood transfusion twice while 23 patients had only one transfusion within the period. In contrast, 51 patients did not receive blood transfusion. Regarding hospitalization in this same group was also based on the number of admis- sion in 12 months prior to study. One patient was hospitalized 5 times, two 4 times, 5 patients were hospitalized 3 times. Furthermore, eight patients were hospitalized 2 times while 33 patients in the group were hospitalized only once. In contrast, 32 patients among the group were not hospitalized (Table 1).

Similarly, the number of significant pain episodes in 12 months preceding the study period was assessed. SCD severity was calculated from the number of hospitalization, blood transfusion and significant pain (significant pain referred to pains necessitating hospital visits (either as outpatient or inpatient and requiring analgesics) (Fig 1).

Table 1. Profile of frequency of blood transfusion, number of hospitalization and Genotypes of the sickle cell patients.

\begin{tabular}{|c|c|c|c|c|c|c|c|c|c|c|c|c|c|c|c|c|}
\hline \multirow[t]{2}{*}{$\begin{array}{l}\text { Age range } \\
\text { (months) }\end{array}$} & \multirow[t]{2}{*}{$\begin{array}{l}\text { Total No } \\
\text { of subject }\end{array}$} & \multicolumn{5}{|c|}{$\begin{array}{l}\text { No of times subject } \\
\text { received blood } \\
\text { transfusion }\end{array}$} & \multicolumn{6}{|c|}{$\begin{array}{c}\text { No of times subject was } \\
\text { hospitalized }\end{array}$} & \multicolumn{4}{|c|}{ Subjects' Genotype } \\
\hline & & 4 & 3 & 2 & 1 & 0 & 5 & 4 & 3 & 2 & 1 & 0 & SC (M) & $S C(F)$ & SS (M) & SS (F) \\
\hline $1-11$ & 2 & - & - & - & 1 & 1 & - & - & - & - & 1 & 1 & 1 & 0 & 1 & 0 \\
\hline $12-60$ & 29 & - & 1 & 2 & 8 & 17 & - & 2 & 3 & 3 & 11 & 10 & 2 & 0 & 15 & 12 \\
\hline $61-120$ & 35 & 1 & - & 1 & 9 & 22 & 1 & - & 2 & 4 & 15 & 11 & 0 & 0 & 17 & 18 \\
\hline $121-180$ & 18 & - & - & 2 & 5 & 11 & - & - & - & 1 & 6 & 10 & 1 & 2 & 8 & 7 \\
\hline Total & $84^{*}$ & 1 & 1 & 5 & 23 & 51 & 1 & 2 & 5 & 8 & 33 & 32 & $4(66.67)$ & $2(33.33)$ & $41(52.5)$ & $37(47.4)$ \\
\hline
\end{tabular}

Figure 1: Severity of sickle cell disease among patients.

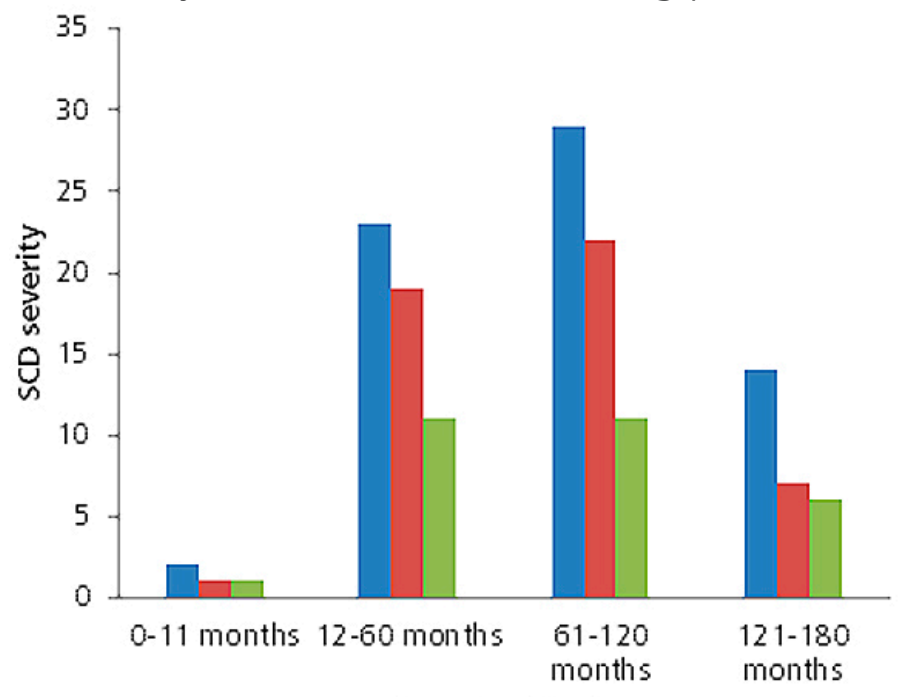

$\square$ No of pain episode

$\square$ No of hospitalization

$\square$ No of blood transfusion

Age of subjects 
Socioeconomic class (SEC) of parents was derived using the occupations and highest educational qualifications of both parents. 24 (30\%) each of the SCD patients' parents were categorized in the upper and middle socioeconomic classes while $32(40 \%)$ were classified in the low socioeconomic class.

Table 2 reflects the distribution of bacterial isolates from the nasopharynx of the 84 SCD patients. A total of 119 bacterial isolates were cultured from 84 patients averaging 1.42 bacteria/ sample. Of the 119 isolated cultured from the nasopharynx of the SCD patients, $44.53 \%$ were Corynebacterium spp comprising of 19 (35.84\%) Corynebacterium xerosis 11 (20.75\%) Corynebacterium diphtheriae, 10 (18.86) Corynebacterium pseudodiphtheriticum, 8 (15.09\%) Corynebacterium ulcerans, 3 (6.66\%) Corynebacterium spp and 2 (3.77\%) Corynebacterium jeikeium. Other Gram positive rods cultured were Arcanobacterium haemolyticum 6 (5\%) of the total 119 cultured, Bacillus subtilis was 3 (2.5\%), Actinomyces isrealli 3 (2.5\%) and Norcadia asteroids 1 (0.84\%). Amongst the Gram positive cocci (Staphylococci) constituted $7.5 \%$ of the total bacterial isolates with CONS being $55.5 \%$ of the Staphylococci and S. aureus $45.5 \%$. Streptococci constitute $(2.5 \%)$ of the total bacterial isolates seen, all of which were $S$. pneumoniae isolates. The lactose fermenters constitute $9.24 \%$ of the total bacteria consisting of Klebsiella pneumoniae $3(27.27 \%)$, E. coli, Enterobacter aerogenes and Citrobacter freundii 2 (18.18\%) each and Citrobacter diversus and Klebsiella oxytoca 1 (9.09\%) each. The non- lactose fermenters were $30(25.21 \%)$ of the total bacterial isolates of which, 7 (23.33) were Pseudomonas aeruginosa, Streptobacillus moniliformis 6 (20\%) each, 5 (16.66\%) each of Heamophilus influenzae and Sarcina spp, Salmonella enteritidis $3(10 \%)$ and Shigella dysenteriae, Moraxella catarrhalis 2 (6.66\%) each.

The antibiotic resistant pattern of the four pathogens is presented in Table 3. Similarly Table 4 repre-
Table 2. Distribution of bacterial isolates cultured from the nasopharynx of SCD subjects.

\begin{tabular}{|c|c|c|c|}
\hline & Bacterial isolates & $\begin{array}{c}\text { Total } \\
\text { no of } \\
\text { bacterial } \\
\text { cultured }\end{array}$ & $\begin{array}{l}\text { Total } \\
\text { No } \\
(\%)\end{array}$ \\
\hline \multicolumn{4}{|l|}{ Bacilli } \\
\hline \multirow{10}{*}{$\begin{array}{l}\text { Gram } \\
\text { Positive } \\
\text { Rods }\end{array}$} & Corynebacterium xerosis & 19 & 15.96 \\
\hline & $\begin{array}{l}\text { Corynebacterium } \\
\text { diphtheriae }\end{array}$ & 11 & 9.24 \\
\hline & $\begin{array}{l}\text { Corynebacterium } \\
\text { pseudodiphtheriticium }\end{array}$ & 10 & 8.4 \\
\hline & Corynebacterium ulcerans & 8 & 6.7 \\
\hline & $\begin{array}{l}\text { Arcanobacterium } \\
\text { heamolyticum }\end{array}$ & 6 & 5.0 \\
\hline & Corynebacterium spp & 3 & 2.5 \\
\hline & Bacillus subtilis & 3 & 2.5 \\
\hline & Actinomyces isrealli & 3 & 2.5 \\
\hline & Corynebacterium jeikeium & 2 & 1.7 \\
\hline & Norcadia asteroides & 1 & 0.84 \\
\hline \multicolumn{4}{|c|}{ Gram Positive Cocci } \\
\hline & $\begin{array}{l}\text { CONS (coagulase negative } \\
\text { Staphylococci) }\end{array}$ & 5 & 4.2 \\
\hline & Staphylococci aureus & 4 & 3.4 \\
\hline & $\begin{array}{l}\text { Streptococcus } \\
\text { pneumoniae }\end{array}$ & 3 & 2.5 \\
\hline \multicolumn{4}{|c|}{ Gram Negative Rods } \\
\hline \multirow{6}{*}{$\begin{array}{l}\text { Lactose } \\
\text { fermenters }\end{array}$} & Klebsiella pneumoniae & 3 & 2.5 \\
\hline & Escherichia. coli & 2 & 1.7 \\
\hline & Enterobacter aerogenes & 2 & 1.7 \\
\hline & Citrobacter freundii & 2 & 1.7 \\
\hline & Citrobacter diversus & 1 & 0.84 \\
\hline & Klebsiella oxytoca & 1 & 0.84 \\
\hline \multirow{7}{*}{$\begin{array}{l}\text { Non } \\
\text { lactose } \\
\text { fermenters }\end{array}$} & Pseudomonas aeruginosa & 7 & 5.9 \\
\hline & $\begin{array}{l}\text { Streptobacillus } \\
\text { moniliformis }\end{array}$ & 6 & 5.0 \\
\hline & Heamophilus influenzae & 5 & 4.2 \\
\hline & Sarcina spp & 5 & 4.2 \\
\hline & Salmonella enteritidis & 3 & 2.5 \\
\hline & Shigella dysenteriae & 2 & 1.7 \\
\hline & Moraxella catarrhalis & 2 & 1.7 \\
\hline Total & & 119 & $(99.92 \%)$ \\
\hline
\end{tabular}


Table 3. Antibiotic resistant pattern of potential pathogenic bacterial isolates cultured from the nasopharynx of SCD subjects at the Wesley Guild Hospital, Ilesha

\begin{tabular}{|c|c|c|c|c|c|c|c|c|c|c|c|c|c|c|c|}
\hline 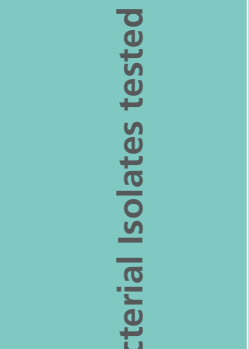 & 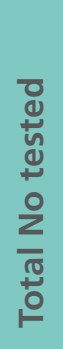 & 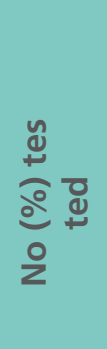 & \multicolumn{3}{|c|}{ 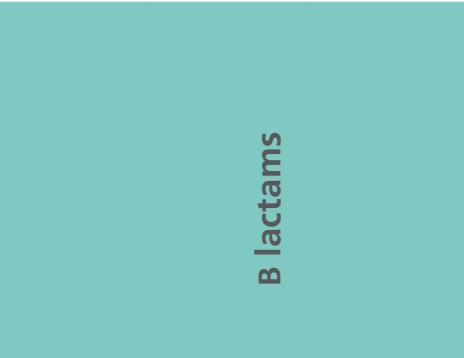 } & 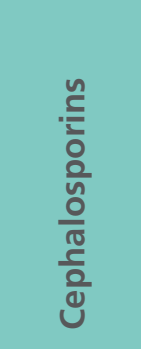 & $\begin{array}{l}\frac{n}{0} \\
\frac{0}{0} \\
0 \\
\frac{0}{\pi} \\
\Sigma\end{array}$ & 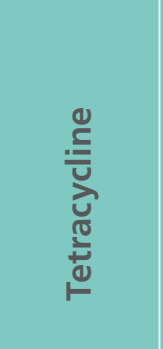 & \multicolumn{3}{|c|}{ 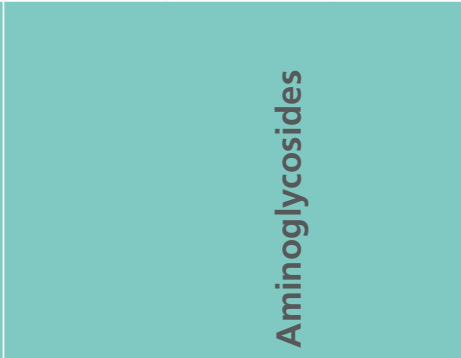 } & \multirow{2}{*}{ 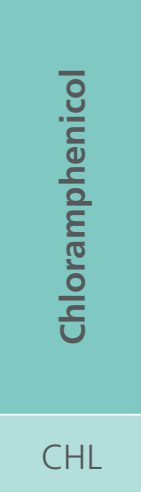 } & \multirow{2}{*}{$\begin{array}{c}\frac{y}{0} \\
\frac{0}{0} \\
\frac{c}{3} \\
\text { ơ } \\
\text { NAL }\end{array}$} & \multirow{2}{*}{$\begin{array}{l}\text { y } \\
\frac{c}{0} \\
\frac{0}{0} \\
\frac{c}{3} \\
\frac{\overrightarrow{0}}{0} \\
\frac{0}{0} \\
\frac{0}{3} \\
\text { CIP }\end{array}$} & \multirow{2}{*}{ 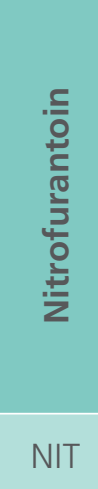 } \\
\hline & & & $A \cup G$ & AMP & OXA & CRO & ERY & TET & STR & GEN & KAN & & & & \\
\hline $\begin{array}{l}\text { Haemophilus } \\
\text { influenzae }\end{array}$ & 5 & 5 & $3(60)$ & $4(80)$ & $4(80)$ & $4(80)$ & $3(60)$ & $5(100)$ & $2(40)$ & 0 & 0 & $5(100)$ & $5(100)$ & $3(60)$ & $3(60)$ \\
\hline $\begin{array}{l}\text { Staphylococcus } \\
\text { aureus }\end{array}$ & 4 & 4 & $1(25)$ & $4(100)$ & 0 & 0 & $4(100)$ & $1(25)$ & 0 & $1(25)$ & 0 & 0 & $4(100)$ & 0 & 0 \\
\hline $\begin{array}{l}\text { Streptococcus } \\
\text { pneumoniae }\end{array}$ & 3 & 3 & $3(100)$ & $3(100)$ & $3(100)$ & $3(100)$ & 0 & 1 (33.33) & $2(66.67)$ & 0 & 0 & $3(100)$ & $3(100)$ & 0 & 0 \\
\hline $\begin{array}{l}\text { Moraxella } \\
\text { catarrhalis }\end{array}$ & 2 & 2 & $1(50)$ & $2(100)$ & $2(100)$ & $2(100)$ & $1(50)$ & 0 & 0 & 0 & 0 & $2(100)$ & $2(100)$ & 0 & 0 \\
\hline Keys to abbrevia & $: T$ & $\begin{array}{l}\text { tracyc } \\
\text { hlorar } \\
\text { paren }\end{array}$ & $\begin{array}{l}\text { STREP = } \\
\text { enicol; } E \\
\text { is=Num }\end{array}$ & $\begin{array}{l}\text { reptomy } \\
=\text { Erythr } \\
\text { in } \%\end{array}$ & $\begin{array}{l}\text {; } \mathrm{AMP}= \\
\text { ycin; K }\end{array}$ & $\begin{array}{l}\text { npicillin; } \\
=\text { Kanan }\end{array}$ & $\begin{array}{l}\mathrm{EN}=\mathrm{Ge} \\
\text { in; NIT = }\end{array}$ & $\begin{array}{l}\text { mycin; A } \\
\text { itrofuran }\end{array}$ & $\begin{array}{l}\mathrm{G}=\text { Augm } \\
\text { in; } C I P=C\end{array}$ & $\begin{array}{l}\text { tin; CR } \\
\text { rofloxa }\end{array}$ & $\begin{array}{l}\text { Ceftr } \\
\text { NAL }\end{array}$ & $\begin{array}{l}\text { ne; OXA } \\
\text { lidixic ac }\end{array}$ & Oxacillin; & & \\
\hline
\end{tabular}


Table 4. Multiple Antibiotic Resistance Index of the predominant pathogenic bacterial isolates cultured from the nasopharynx of SCD subjects at Wesley Guild Hospital, Ilesha.

\begin{tabular}{|c|c|c|c|c|c|}
\hline $\begin{array}{l}\text { Class of } \\
\text { Antibiotic }\end{array}$ & Antibiotics used & $\begin{array}{l}\text { Total no. of } \\
\text { isolates tested }\end{array}$ & $\begin{array}{l}\text { Total no. (\%) } \\
\text { resistant }\end{array}$ & $\begin{array}{l}\text { Total no. (\%) } \\
\text { susceptible }\end{array}$ & MAR index \\
\hline \multirow[t]{3}{*}{$\beta$-lactams } & Ampicillin & 14 & 13 & 1 & 0.92 \\
\hline & Augmentin & 14 & 8 & 6 & 0.57 \\
\hline & Oxacillin & 14 & 9 & 5 & 0.64 \\
\hline Cephalosporins & Ceftriaxone & 14 & 9 & 5 & 0.64 \\
\hline Tetracyclines & Tetracycline & 14 & 7 & 7 & 0.50 \\
\hline Macrolides & Erythromycin & 14 & 8 & 6 & 0.57 \\
\hline \multirow[t]{3}{*}{ Aminoglycosides } & Streptomycin & 14 & 4 & 10 & 0.28 \\
\hline & Gentamycin & 14 & 1 & 13 & 0.07 \\
\hline & Kanamycin & 14 & 0 & 14 & 0 \\
\hline Chloramphenicol & Chloramphenicol & 14 & 10 & 4 & 0.71 \\
\hline Quinolones & Nalidixic acid & 14 & 14 & 0 & 1.0 \\
\hline Fluoroquinolones & Ciprofloxacin & 14 & 3 & 11 & 0.21 \\
\hline Nitrofurans & Nitrofurantoin & 14 & 3 & 11 & 0.21 \\
\hline
\end{tabular}

sents the multiple antibiotic resistances of the four pathogens using MAR index.

\section{Discussion and conclusion}

The sickle gene confers an increased susceptibility to infection, especially to certain bacterial pathogens, and at the same time infection provokes a cascade of SCD-specific pathophysiological changes. Africa bears the highest burden of sickle cell disease on the globe. Our study characterized the nasopharyngeal bacterial isolates cultured from 84 Sickle cell disease patients at the infant welfare clinic of the Wesley Guild Hospital, of which 78 (92.85\%) were HbSS of this 41 (52.56\%) were males and 37 (47.44\%) females. In addition, 6 (7.14\%) were HbSC; 4 (66.66\%) males and 2 (33.33\%) females. Despite the fact that over 700 structural haemoglobin $(\mathrm{Hb})$ variants have been identified worldwide, only ( $\mathrm{Hb} \mathrm{S}, \mathrm{Hb} \mathrm{C}$ ) constitutes high frequencies in Africa [8]. Altogether, 119 isolates were cultured from the nasopharynx of the SCD patients, consisting of 78 (65.54\%) Gram positive bacteria comprising 66 (55.46\%) Gram positive rods and 12 (10.08\%) Gram positive cocci dominated and Gram negative isolates was (34.45\%) of total bacterial recovered from SCD patients. The predominant Gram positive organism was Corynebacterium spp comprising $44.53 \%$ of the Gram positive rods of which Corynebacterium xerosis predominated. The Gram positive cocci were 5 (4.20\%) CONS and S. aureus $4(3.36 \%)$ and 3 (2.52\%) S. pneumoniae underscoring a low rate of nasopharyngeal colonization with these organisms in this center which may be attributable with the prophylactic use of penicillin in this center. Despite the high nasopharyngeal carriage which often is a determinant for invasive pneumococci in some regions [9], it is puzzling to note high carriage rates with low rates of invasive pneumococcal disease in sub-Saharan Africa $[10,11]$. According to Kizito et al., [11] a significantly low rate of pneumococ- 
Vol. 8 No. 99 doi: $10.3823 / 1698$ cal bacteremia in Ugandan children with sickle cell disease $(6 \%, 3 / 47)[12]$, and other studies have indicated low pneumococcal bacteremia in Nigerian children [13, 14]. However, in Zambia low rate of pneumococci frequency was attributable to strict antibiotic policy of the government that reduced access to sale of over the counter drugs. Our data showed widespread multiple antibiotic resistance among the four pathogens we tested. Our study shows all the $5 \mathrm{H}$. influenzae isolates tested were resistant to tetracycline, chloramphenicol and nalidixic acid. 4 isolates were resistant to ampicillin, oxacillin and third generation cephalosporin-ceftriaxone while 3 isolates were resistant to augumentin, erythromycin, ciprofloxacin and nitrofurantoin. In addition, two of $H$. influenzae isolates were also resistant to streptomycin but none was resistant to gentamycin and kanamycin. Similarly, of the four S. aureus isolates cultured, all were resistant to ampicillin, erythromycin and nalidixic acid and 1 isolate was resistant to augumentin, tetracycline and gentamycin but none was resistant to oxacillin, ceftriaxone, streptomycin, kanamycin, chloramphenicol, ciprofloxacin and nitrofurantoin. Furthermore, our results reveal among the three $S$. pneumoniae isolates cultured from the nasopharynx, all were resistant to the beta lactams antibiotics, augumentin, ampicillin, oxacillin and ceftriaxone. Two of the S. pneumoniae isolates were resistant to streptomycin and one isolate to tetracycline, chloramphenicol and nalidixic acid. In contrast, none of the isolates was resistant to erythromycin, gentamycin, kanamycin, ciprofloxacin and nitrofurantoin. Finally, among the MoraxeIla catarrhalis isolates tested, all were resistant to ampicillin, oxacillin, ceftriaxone, chloramphenicol, nalidixic acid. However, 1 isolate was resistant to augumentin, erythromycin but all were sensitive to the other antibiotic used (Table 3). Because of susceptibility to severe pneumococcal infection, children with sickle cell disease (SCD) routinely receive penicillin prophylaxis which unintentionally increased the rates of penicillin resistance reported throughout the world, this practice has led to emergence of penicillin resistant $S$. pneumoniae (PRSA) untamable to treatment with $\beta$-lactams in particular and also a variety of different antibiotics.

The predominance of Corynebacterium spp seen in our study among these SCD patients may also be related to indigenous microflora which represents commensals of the nasopharynx that limit the growth of pathogenic organisms by phenomenon of microbial antagonism. Furthermore, Gram negative organisms accounted for $34.46 \%$ of the nasopharyngeal isolates comprising of 11 (26.82\%) lactose fermenters and 30 (73.17\%) non lactose fermenters. Colonization with Gram negative organisms specifically with lactose fermenters- E. coli, Klebsiella, Citrobacter and Enterobacter spp is of concern but may be attributable to patients' personal hygiene. It is interesting to note that $40 \%$ of the population studied comes from low socioeconomic group (15) who live in overcrowded living conditions and lack portable drinking water are therefore at higher risk of parasitic infections such as malaria and diarrhoea. The low rate of nasopharyngeal colonization in children at this center with Haemophilus influenzae 5 (4.2\%) and S. pneumoniae, may be attributed to administration of vaccines early in life in this environment.

The multiple antibiotic resistance (MAR) seen in our study was widespread among the four predominant pathogens. The MAR indices for the beta-lactams for example, comprising of ampicillin, augumentin, oxacillin and ceftriaxone were 0.92, $0.57,0.64$ and 0.64 respectively. For tetracycline, the MAR value was 0.50; and for erythromycin 0.57. Regarding aminoglycosides comprising of streptomycin, gentamycin and kanamycin their MAR indices were $0.28,0.07$ and 0.00 respectively. For chloramphenicol the MAR index was 0.71, while for nalidixic acid it was 1.00. When we analyzed ciprofloxacin and nitrofurantoin, MAR value was 0.21 for each antibiotic. These results 
suggest widespread multiple antibiotic resistance among organisms cultured from SCD patients. Our study showed an unexpected high frequency of nasopharyngeal colonization rarely seen with indigenous microflora specifically Corynebacterium spp at this center. This finding suggests routine use of prophylactic penicillin may have suppressed $S$. pneumoniae nasopharyngeal colonization among the subjects. It also suggests routine vaccination of infants and children in the center may be assisting in reducing the frequency of colonization by $S$. pneumoniae and Haemophilus influenzae among subjects. Our data show beta- lactam antibiotics are virtually ineffective against the organisms cultured from these SCD patients compared with aminoglycosides, quinolones and nitrofurantoin. This observation is of epidemiological significance in the event of an epidemic in this center. The widespread resistance recorded for the majority of nasopharyngeal isolates recorded in our study requires urgent and necessity of instituting effective antibiotic policy in this center to reduce the frequency of drug- resistant in this population.

Studies have shown SCD not only originates from abnormality of RBC but also is a multisystem disorder, affecting virtually every organ of the human body. These conditions include haemolysis, many haemotological complications, vasoocclusion, infection and organ dysfunction (8). Our study reveals 49 (60.49\%) of the SCD patients were hospitalized at least once. Thirty (61.22\%) of these patients also received blood transfusion at least once. SCD patient suffers chronic haemolytic anaemia which allows the patient to carry on normal activities at steady state hemoglobin with narrow reserve capacity to accommodate strenuous physical activities $[16,17,18,19]$. The role of the blood transfusion in the SCD patient is meant at increasing the level of hemoglobin, improve oxygen delivery and reduce proportion of sickle RBCs in circulation [8]. In addition, infection caused by $H$. influenzae and S. pneumoniae is a major cause of concern for children with SCD with haemoglobulin SS; HbSS and HbSC as these children are at risk of bacteremia and chronic anemia that lead to early loss of splenic function [6]. Our results, however suggest despite their genotypes, these children had low rate of colonization with $H$. influenzae and S. pneumoniae at this center which is interesting and may lead to further reduction in infection with these organisms. Furthermore, the preponderance of indigenous microflora in nasopharynx of these children by organisms such as Corynebacterium spp most of which are commensals, are in competition with pathogens because of microbial antagonism, an aspect of innate immunity will reduce the colonization with pathogens. Besides, administration of both pneumococci and influenzae vaccines in booster doses may also lower the rate of nasopharyngeal colonization [20]. In conclusion, Gram positive bacterial isolates predominated in this study (65.45\%) compared to (34.55\%) of Gram negative bacteria. However Corynebacterium spp predominated. Low rate of nasopharyngeal colonization with Haemophilus influenzae, Streptococcus pneumoniae and Staphylococcus aureus strains was recorded. The study also recorded widespread multiple drug resistance among most isolates colonizing the nasopharynx of SCD in this center which is worrisome suggesting for urgent institution of effective antibiotic policy to stem the tide of multidrug resistant organisms in this center.

\section{References}

1. Adepoju, W. and Onwuzurike, E. (2015). Foundation seeks research into sickle cell disorder. The Nation. March, 24 pp47.

2. Mori, L. A., Netto de Oliveira, L. S., Oliveria, L.S. C., Pimenta, F. C. (2010). Nasopharyngeal Gram-negative bacilli colonization in Brazilian children attending day-care centres. Brazilian Journal of Microbiology. Vol 41no1. Doi 10.1590/S151783822010000100005 .

3. Okuonghae, H. O., Nwankwo, M. U. and Offor, E. C. (1993). Pattern of bacteraemia in febrile children with sickle cell anaemia. Ann Trop Paediatr. 13 (1): 55-64. 
4. Sylvia C. Harris, Yvonne Davis, Gang Chen, Joan Chesney, Najat C. Daw, Judith A. Wilimas, Winfred C. Wang, Gerald J. Presbury, Royce E. Joyner (1997). Nasopharyngeal Carriage of Penicillin resistant Streptococcus pneumoniae in Children with Sickle Cell Disease. Pediatrics: 99 (7). DOI: 10.1542/peds.99.4.e

5. Patricia Belintani Blum Fonseca, Calil Kairalla Farhat, Regina Célia de Menezes Succi, Antônia Maria de Oliveira Machado, Josefina Aparecida Pellegrini Braga (2013). Penicillin Resistance in Nasopharyngeal Streptococcus pneumoniae among Children with Sickle Cell Disease Immunized with 7-Valent Pneumococcal Conjugate Vaccine. World Journal of Vaccines 3, 25-31

6. Overturf, G. D., Powars, D. and Baraff, L. J. (1977). Bacterial meningitis and septicemia in sickle cell disease. Am J Dis Child. 131 (7): 784-787.

7. Kwambana, B. A., Barer, M. R., Bottomley, C., Adegbola, R. A. and Antonio, M. (2011). Early acquisition and high nasopharyngeal co-colonisation by Streptococcus pneumoniae and three respiratory pathogens amongst Gambian new-borns and infants. BMC Infect Dis, 11: 175.

8. Makani, J. S. Ofori-Acqua, F., Nnodu, O., Wonkam, A. and, Ohene- Frempong, K., (2013). Sickle Cell Disease: New Opportunites and Challenges in Africa. The Scientific World Journal. Vol 2013, article ID 193252.

9. Bogaert, D., De Groot, R. and Hermans, P.W. (2004). Streptococcus pneumoniae colonisation: the key to pneumococcal disease. Lancet Infect Dis, 4 (3): 144-154.

10. Battersby, A. J., Knox-Macaulay, H. H. and Carrol, E. D. (2010). Susceptibility to invasive bacterial infections in children with sickle cell disease. Pediatr Blood Cancer 55 (3): 401-406.

11. Kizito, M. E., Mworozi, E., Ndugwa, C. and Serjeant, G. R. (2007). Bacteraemia in homozygous sickle cell disease in Africa: is pneumococcal prophylaxis justified? Arch Dis Child, 92 (1): 2123.

12. David P Kateete, Henry Kajumbula, Deogratias H, KadduMulindwa and Augustine K Ssevviri (2012). Nasopharyngeal carriage rate of Streptococcus pneumoniae in Ugandan children with sickle cell disease. BMC Research Notes 5: 28 doi: 10.1186/1756-0500-5-28

13. Akuse, R. M. (1996). Variation in the pattern of bacterial infection in patients with sickle cell disease requiring admission. J Trop Pediatr, 42 (6): 318-323. PubMed Abstract |

14. Akinyanju, O. and Johnson, A. O. (1987). Acute illness in Nigerian children with sickle cell anaemia. Ann Trop Paediatr, 7 (3): 181-186. PubMed Abstract

15. Oyedeji, G. A. (1985). Socioeconomic and cultural background of hospitalized children in Ilesa. Nig J Paediatr. 13: 111-118.

16. Stegenga, K. A. Ward-Smith, P., Hinds, P. S., Routhieaux, J. A., and Woods, G. M. (2004). Quality of life among children with sickle cell disease receiving chronic transfusion therapy. Journal of Pediatric Oncology Nursing, vol 21, no.4, pp207-213.
17. Prasad, R., Hasan, S., Castro, O., Perlin, E. and Kim, K. (2003). Long-term outcomes in patients with sickle cell disease and frequent vaso-occlusive crises. American Journal of Medical Sciences. Vol 325, no 3, pp107-109.

18. Telen, M. J. (2003). Principles and problems of transfusion in sickle cell disease. Seminars in Hematology, vol 38, no 4, pp 315-323.

19. Ohene-Frempong, K. (2001). Indications for red cell transfusion in sickle cell disease. Seminars in Hematology. Vol 38, no.1, supplement1, pp.5-13.

20. McCavit, T. L., Quinn, Techasaensiri, C. and Rogers, Z.R. (2011). J Pediatr.; 1583- 505.

\section{Comment on this article:}

\section{A $[$ in $8+\mathbf{S}$ P}

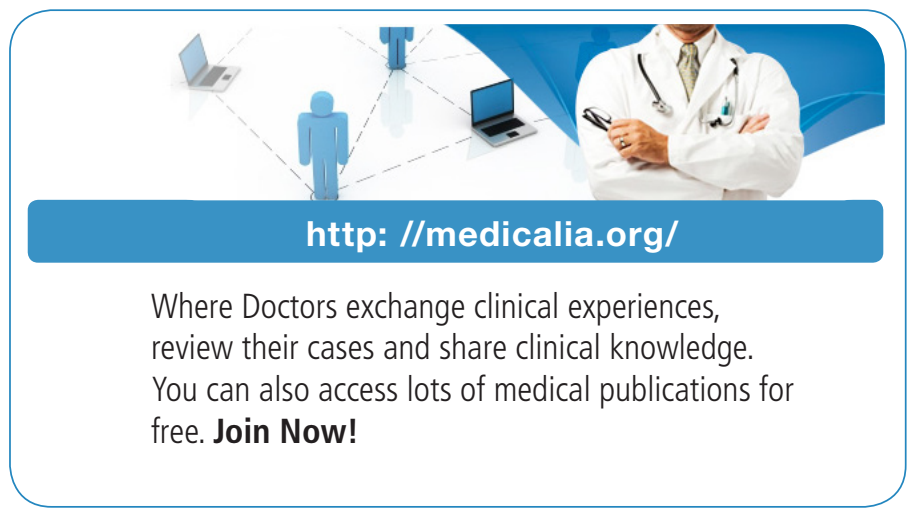

Publish with iMedPub

\section{http: //www.imed.pub}

International Archives of Medicine is an open access journal publishing articles encompassing all aspects of medical science and clinical practice. IAM is considered a megajournal with independent sections on all areas of medicine. IAM is a really international journal with authors and board members from all around the world. The journal is widely indexed and classified Q1 in category Medicine. 